\title{
Blanchot e o canto das sereias: uma alegoria da literatura
}

Ângelo Bruno Lucas de Oliveira

UFC

\begin{abstract}
Resumo
Estre trabalho realiza uma análise da literatura a partir da alegoria que Maurice Blanchot utiliza em seu O livro por vir: o canto das sereias. Em sua alegoria, o teórico retoma o episódio de Homero em que Ulisses ouve o canto dos seres sobrenaturais e sobrevive. Todo escritor, para Blanchot, repetiria o feito do personagem homérico, uma vez que, no ato de criação, ele seria movido por uma força que náo compreende, uma força que move a literatura. Essa força recebe a denominação, dentre outras, de fala errante. Segundo Blanchot, essa fala duelaria com a razão e as normas que o escritor conhece. Desse embate nasce a literatura, como fruto de uma região fronteiriça, como algo que está sempre aquém e apontando sempre para além. Nesta alegoria, Blanchot reúne grande parte do pensamento que desenvolveria mais tarde em outras de suas obras, que também servem de base teórica a este escrito, tais como $O$ espaço literário e $A$ conversa infinita. Também é utilizado o famoso ensaio anterior a $O$ livro por vir, "A literatura e o direito à morte". Outros estudiosos são utilizados para reforçar o pensamento blanchotiano, tais como Barthes $(2004,2007)$ e Heidegger (s.d., 2008).
\end{abstract}

Palavras-chave: Literatura; Maurice Blanchot; escrita.

\begin{abstract}
This paper performs an analysis of the literature from the allegory that Maurice Blanchot uses in The book to come: the song of the sirens. In his allegory, the theorist summarizes Homer's episode when Odysseus hears the song of the sirens and survives. Every writer, for Blanchot, repeats the feat of the Homeric character, since, at the time of creation, a force moves him and he does not understand. This is the force that drives the literature and it receives the designation, among many others, wandering speech. According to Blanchot, this speech duels with reason and the rules the writer knows. From this duel rises the literature as a result of a border region, as something that is always short and pointing to something that is beyond. In this allegory, Blanchot brings together much of the thought he later developed in other works, which also serves as theoretical basis for this writing, such as The space of literature and The infinite conversation. The famous essay "Literature and the right do death" is also used. Others scholars attend to reinforce the Blanchot's thought, such as Barthes (2004, 2007) and Heidegger (s.d., 2008).
\end{abstract}

Keywords: Literature; Maurice Blanchot, writing. 
1. BLANCHOT, Maurice.

O livro por vir, 2005, p. 293.

2. Ibidem, p. 294.

3. BLANCHOT, Maurice.

O espaço literário, 2011, p.11.
As ideias de Maurice Blanchot acerca da literatura vão de encontro a muitos clássicos conceitos que se têm tecido a respeito dela. Contrariando, por exemplo, a clássica descrição da literatura como imitaçáo da realidade, atribuída a Aristóteles, Blanchot reconhece o texto artístico não como uma cópia ou representação do mundo, mas como "aquilo que não se descobre, não se verifica e não se justifica jamais diretamente" ${ }^{\text {.1 Longe }}$ de ser algo tranquilo sobre o qual repouse o peso dos anos e da tradição, a literatura, para ele, é um constante movimento e uma ininterrupta busca de se atingir o inalcançável. Ele chega mesmo a dizer: "Nem é mesmo certo que a palavra 'literatura' ou a palavra 'arte' correspondam a algo de real, de possível ou de importante"2.

Num primeiro lançar de olhos, pode parecer que Blanchot dá à literatura uma importância menor, que ele a enxerga como um algo descartável no mundo, para o que algumas pessoas costumam dedicar a atenção. Mas não é assim. Essa é uma das armadilhas que Blanchot dispóe no decurso de sua escrita. Como teórico, ele não abriu mão de uma linguagem altamente sugestiva e eivada de imagens. Para falar de literatura, ele não se permitiu outra linguagem que não a do próprio objeto de sua escrita. Assim, pois, julgar suas afirmaçōes requer cuidado. Ao duvidar, por exemplo, da importância, da possibilidade e da realidade da literatura, como fez na passagem transcrita, o autor, longe de depreciar o fato literário, quis evidenciar seu caráter intangível. Pois assim se constitui, para ele, a literatura: sua marca é a impossibilidade. Desse modo, nada de fixo está posto; nem mesmo o livro, em sua existência física e seu formato limitado, é capaz de conter esse algo inominável que se denomina obra. Para ele, o espaço da literatura não é o espaço do real, daí a dúvida acerca de sua realidade. O lugar da literatura é o espaço para além do infinito, do absoluto, no caminho do qual o escritor renega o mundo físico e sua existência real para — se não fazer, pelo menos tentar - dar corpo à arte.

Em $O$ espaço literário, o teórico apresenta-nos, logo no primeiro capítulo, a noção de solidão essencial, própria da literatura. Valendo-se sempre de uma linguagem incomum, ele toma o cuidado de esclarecer: solidão não é recolhimento. A este último ele associa a decisão de muitos escritores de isolarem-se do mundo para escrever. A solidão essencial não estaria, sob sua óptica, ligada ao ator da escrita, mas ao próprio objeto, a obra. Pertencente a uma esfera que escapa ao conhecimento, ela protagonizaria uma solidão que a configuraria como tal. Seu isolamento é táo intenso que nem mesmo o escritor pode partilhar de sua companhia. Blanchot diz: "Aquele que escreve a obra é apartado,

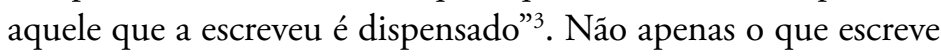
é extirpado da obra, como também quaisquer fatores que lhe sejam externos, sejam eles sociais, históricos ou pessoais. Existindo 
independente, a obra destitui o escritor da elevada posiçáo que sempre ocupou como artista-criador e o obriga a uma anulação de seu próprio eu. "A obra exige que o homem que escreve se sacrifique por ela [...] que se torne ninguém, o lugar vazio e animado onde ressoa o apelo da obra" ${ }^{4}$. Essa ideia seria mais tarde apresentada por Roland Barthes sob o polêmico título de "A morte do autor". Sob a perspectiva barthesiana, "é a linguagem que fala, não o autor" e "o nascimento do leitor deve pagar-se com a morte do Autor"s. Blanchot vai um pouco além.

Para o nosso teórico, a exclusão do autor da obra não se dá devido ao surgimento do leitor como entidade construtora do escrito, ela se manifesta sob outra instância. De acordo com seu pensamento, o escritor é apartado da obra porque ele é o autor de um livro, "mas o livro ainda não é a obra". Estabelecendo uma distinção entre estes termos, Blanchot torna mais nítida a sua noção da obra como algo inatingível. Ele diz: "O escritor pertence à obra, mas o que lhe pertence é somente um livro, um amontoado de palavras estéreis, o que há de mais insignificante no mundo" . Com essa afirmação, ele exalta a obra um patamar acima do próprio escritor, fazendo deste um pertence daquela e atribuindo a ele, escritor, apenas um livro, objeto limitado e sem função prática na existência cotidiana. $\mathrm{O}$ livro é o instrumento único do qual o escritor se vale para atingir a obra. Este sim possui um contexto histórico e social que lhe dá vida; lê-lo, contudo, sob esta única óptica é afastar a obra e fazer do livro um "livro verdadeiro", que, na terminologia blanchotiana, é um livro que "se oferece como uma rede solidamente tecida de significações determinadas, como um conjunto de afirmações reais" ou em outras palavras, um livro não literário.

Uma vez escrito o livro, ele tende a rumar na direção da obra, obra que, a nosso ver, Blanchot compreende como origem, na acepção em que Heidegger a utilizou em seu $A$ origem da obra de arte, onde escreve: "Origem significa aqui aquilo a partir do qual e através do qual uma coisa é o que é, e como é. [...] A origem de algo é a proveniência de sua essência”" Sendo uma essência primeira, anterior ao próprio artista, compreende-se bem por que Blanchot entende a obra como ausente e solitária do escritor, bem como de outras instâncias que a ele estejam ligadas. Não sendo produção de um indivíduo, mas antecedendo a ele, ela é a manifestação de uma fala neutra, de uma fala original, um murmúrio incompreensível que exige do escritor uma ação, a única que lhe cabe: escrever. $\mathrm{Na}$ sua escrita, contudo, o indivíduo vê-se diante de um problema: como dar corpo ao inominável, como falar do silêncio original, como, valendo-se apenas de palavras, chegar àquele ponto crônico em que a obra simplesmente é? Blanchot não vê saída. É por isso que nos fala da impossibilidade da literatura. Se a obra é solitária, como ele próprio afirma, isolada de quaisquer ligaçóes com o mundo real,
4. Idem. O livro por vir, 2005, p.316.

5. BARTHES, Roland. "A morte do autor", 2004, p. 59, 64.

6. BLANCHOT, Maurice.

O espaço literário, 2011, p. 13.

7. Ibidem, p. 13.

8. Ibidem, p. 211.

9. HEIDEGGER, Martin. A origem da obra de arte, s.d., p. 11. 
10. BARTHES, Roland. Aula, 2007, p. 22. como, utilizando-se de palavras reais, fazer-se presente diante dela? Neste ponto, o pensamento de Roland Barthes parece-nos muito próximo, mais uma vez, do de Blanchot, quando aquele afirma: "ela [a literatura] é também obstinadamente irrealista; ela acredita sensato o desejo do impossível" ${ }^{10}$. O impossível para Barthes corresponde à realidade, incapaz de ser transposta, em sua existência pluridimensional, para a existência unidimensional do texto. Essa discrepância é, para ele, o motor da arte literária que, nunca contente com o malogro, parte na tentativa de tornar real de outro modo seu objetivo. O pensamento blanchotiano segue uma lógica semelhante, conquanto para este o real não seja a meta a ser atingida, mas uma instância da qual é mister se libertar para que se atinja a obra.

A ela, a obra, Blanchot referiu-se de diferentes formas ao longo de seus livros, sempre associando-a a uma fala misteriosa. Ora chamada de "fala errante", ora de "linguagem sem entendimento", ou ainda de "fala secreta", "rasgão na espessura do silêncio" e "obscura exigência", essa obra inatingível, diferente da obra enquanto produto de uma escrita, configura-se como um dos elementos centrais da poética blanchotiana, sobre o qual vale deter-se mais demoradamente.

\section{O canto das sereias}

Conforme já havíamos mencionado, Maurice Blanchot não abre mão, em seus escritos teóricos, de uma linguagem essencialmente poética, marcada por imagens e conceitos incomuns. Dentre as diversas metáforas que cunhou para tratar do fenômeno literário, uma das mais conhecidas é, sem dúvidas, a sua imagem do canto das sereias. Evocando a antiga cena de Homero, Blanchot vale-se do lendário encontro de Ulisses com esses seres sobrenaturais para narrar o náo menos fabuloso encontro do escritor com essa voz que o chama e o obriga a escrever. Como essa voz, o canto das sereias é inumano, ancestral e exterior a toda lógica humana, concentrando em si elementos antípodas que, ao invés de se excluírem, convivem e contribuem para a existência paradoxal dessa irreal potência. Vejamos a descrição que nos dá Blanchot:

As Sereias: consta que elas cantavam, mas de uma maneira que não satisfazia, que apenas dava a entender em que direção se abriam as verdadeiras fontes e a verdadeira felicidade do canto. Entretanto, por seus cantos imperfeitos, que náo passavam de um canto ainda por vir, conduziam o navegante em direção àquele espaço onde o cantar come- 
çava de fato. Elas não o enganavam, portanto, levavam-no realmente ao objetivo. Mas, tendo atingido o objetivo, o que acontecia? O que era esse lugar? Era aquele onde só se podia desaparecer, porque a música, naquela região de fonte e origem, tinha também desaparecido, mais completamente do que em qualquer outro lugar do mundo; mar onde, com orelhas tapadas, soçobravam os vivos e onde as Sereias, como prova de sua boa vontade, acabaram desaparecendo elas mesmas. ${ }^{11}$

Mais que uma fala, esse canto assemelha-se a um murmúrio, não satisfaz porque nâo se faz ouvir direito. É antes uma possibilidade, parece encaminhar-se para o lugar verdadeiro onde se pode ouvir o canto perfeito; daí o autor o chamar de "canto ainda por vir". Sob este aspecto ele não é enganador, porquanto se revela como sombra e conduz "realmente ao objetivo". Este sim é que é estranho e incômodo, pois é nele que se abriga o verdadeiro perigo do canto das sereias. Uma vez chegado ali, que pode mais o navegante, senão desaparecer? Como regiáo de fonte e origem do canto, o objetivo, o ponto central, se constitui do mais puro e profundo silêncio, é mar onde afundam os navegantes e mesmo as sereias. Mas por quê?

Porque esse é o lugar da origem, o ponto solitário a que os homens querem achegar-se. Longe de figurar como um jardim frutífero em que a abundância governa, ele aparece como sendo um vazio, "um lugar de aridez e secura onde o silêncio, como o ruído, barrasse, naquele que havia tido aquela disposição, toda via de acesso ao canto" ${ }^{12}$. Saber onde cessa o canto, porém, não é fácil. O navegante nunca sabe ao certo quando a voz se calou, é impossível para ele discernir o canto do barulho das vagas. Daí que todos aqueles que se aproximaram desse ponto secreto "apenas chegaram perto, e morreram por impaciência, por haver prematuramente afirmado: é aqui; aqui lançarei âncora" ${ }^{13}$. Outros, é Blanchot quem nos diz, ultrapassaram o ponto; além dele nada viram senão o deserto, e perderam-se também, sem uma via que lhes proporcionasse o retorno.

Consta que foi Ulisses, o ardiloso rei de Ítaca, o único a ouvir o canto das sereias e não sucumbir. Sua perfídia lhe teria permitido contemplar o espetáculo das sereias sem correr os riscos e sem arcar com as consequências inerentes a isso. Amarrado ao mastro de seu navio, o filho de Laertes contorceu-se e ouviu o inaudível canto, mas em segurança; venceu as sereias, mas, como nos lembra Blanchot, não saiu ileso. "Elas [as sereias] o atraíram para onde ele não queria cair e, escondidas no seio da Odisséia, que foi seu túmulo, elas o empenharam, ele e muitos outros, naquela navegação feliz, infeliz, que é a da narrativa" ${ }^{\prime 14}$. Seu preço, portanto, foi transformar-se em Homero. Movido pela prudência e astúcia que o livraram da certa desdita no mar, o esperto rei perdeu aquele ponto central, diferente de todos os
11. BLANCHOT, Maurice.

O livro por vir, 2005, p. 3.

12. Ibidem, p. 5.

13. Ibidem, p. 4.

14. Ibidem, p. 6. 

ses retornou e permitiu que seu encontro fabuloso achasse lugar nos versos da Odisseia. Permitiu, assim, que o livro se erguesse em lugar da obra.

A perda, porém, não foi completa; conquistou-se a narrativa. Para Blanchot, ela se desenvolve sempre no reflexo do duelo entre Ulisses e as sereias. Nesse duelo, toda perfídia e aptidão, bem como toda prudência e ardil do velho rei são sempre aperfeiçoados e utilizados. A isso ele chama de romance, e contrapóe à narrativa. Para Blanchot, o romance é a navegação prévia, está ligado à paixão dos homens e ao seu tempo. Ele não se ocupa de ir em direçáo a um destino, ele é aventura, entretenimento. É, como disse Hegel, a epopeia do mundo burguês e se ocupa em mostrar e representar a este mundo seus caracteres, costumes e crenças. Ele é claro e seu território é o do dia. Ele se dedica a mostrar aos homens o seu próprio mundo, aquilo que eles são e aquilo que os alegra. Ele faz do tempo humano um jogo e desse jogo, superficialidade. Por outro lado, a narrativa empreende o que o romance não faz. Diferente dele, ela ruma na direção de um ponto específico, quer alcançá-lo. Ela é sempre um único episódio: o do encontro de Ulisses com as sereias.

A narrativa é movimento em direçáo a um ponto, não apenas desconhecido, ignorado, estranho, mas tal que parece não haver, de antemáo e fora desse movimento, nenhuma espécie de realidade, e tão imperioso que é só dele que a narrativa extrai sua atraçáo $[\ldots]^{15}$

O lugar para o qual a narrativa se move é o canto das sereias. Tal como o herói grego, ela se aproxima daquele ambiente de silêncio e origem e, tal como ele, é atraída pela voragem, que encanta e convida à desaparição. Assim como Ulisses, a narrativa acerca-se daquele ponto central e chega muito perto do silêncio original, onde desaparecem todas as palavras e tudo se perde. Diferente do romance, ela possui um propósito, mas isso não a liga ao sossego. Enquanto aquele navega aleatoriamente e faz do entretenimento o seu canto profundo, esta parte em busca do murmúrio ancestral, da fala neutra, que, como vimos, nunca se mostra. Desse modo, sua navegação também se faz infinita. Indo sempre em busca do objetivo, a narrativa retorna com as mãos vazias. Náo tendo nunca completado sua jornada, não tendo nunca ouvido, como Ulisses, o canto completo, ela se transmuta em Homero.

Para que a narrativa exista, nos diz Blanchot, é preciso que alguém tenha vivido o acontecimento e que o conte. $\mathrm{O}$ único acontecimento, porém, é o do encontro de Ulisses. Isso porque, para nosso teórico, toda narrativa não é nunca o relato de um feito, mas o próprio feito. Dessa forma, toda vez que se escreve 
algo, o canto proibido é novamente pronunciado, Ulisses é novamente amarrado ao mastro e novamente sai ileso. Essa é a lei secreta da narrativa. Ela só pode narrar a si própria.

"O poeta é aquele que ouve uma linguagem sem entendimento" 16 . Ele se assemelha, portanto, aos navegadores, absortos diante da misteriosa voz dos monstros marinhos. Seu objetivo é acercar-se da obra em sua solidão essencial, a região de fonte e origem em que tudo, mesmo a música e as sereias, desaparece. Sua meta, entretanto, é impossível, pois ele sente a premente necessidade de escrever. E o que escreve não é nada senão a tentativa frustrada de achegar-se àquela fala ancestral. Desse modo, pois, o poeta, o escritor, é, ao mesmo tempo, Ulisses e Homero. Ele é aquele que se aproxima, que se arrisca a ouvir o canto inaudível, o murmúrio secreto, mas que retrocede e faz daquilo que ouviu a ode. "É ouvindo o Canto das Sereias que Ulisses se torna Homero, mas é somente na narrativa de Homero que se realiza o encontro real em que Ulisses se torna aquele que entra em relação com a força dos elementos e a voz do abismo" 17 . Desse modo, para que a narrativa comece, é necessário que ela já tenha começado, ou seja, para que Homero descreva o acontecimento, é preciso que antes Ulisses tenha ouvido o canto e tenha regressado. Ou ainda: para que o escritor descreva sua busca pela linguagem sem entendimento, é preciso que antes ele a tenha escutado, que a tenha querido. É exatamente por isso que Blanchot aponta outra diferença fundamental entre o romance e a narrativa: o tempo. Acerca do tempo desta última, ele diz: "a narrativa, tem para progredir, aquele outro tempo" ${ }^{18}$. Fruto do embate com a "voz do abismo", a narrativa desprende-se do tempo comum, não lhe segue a ordem. Ela se aproxima da solidão essencial, desprezando as convençôes de passado, presente e futuro e tornando tudo um eterno presente, em que a façanha do grego se mantém sempre atualizada, sempre aqui, sempre agora. Parece-nos que a isso Barthes se referia quando, no seu "A morte do autor", disse: "todo o texto é escrito eternamente aqui e agora"19.

Mas voltemos ao escritor. Tendo retornado de procurar a fala errante que se encontra no centro do canto das sereias, ele, tal como Ulisses, não saiu ileso. Condenado a atualizar e reviver constantemente o acontecido, ele se vê preso num paradoxo: seu poder não é o de dizer. Explicamos: sendo obrigado a contar seu encontro com as sereias, de que falará o escritor? Como enquadrar aquele canto defeituoso e cheio de poder, que é o centro de sua mensagem literária, dentro de palavras, se ele é exatamente o lugar em que cessam todas elas? Sua necessidade de escrever "está ligada à abordagem desse ponto onde nada pode ser feito das palavras" ${ }^{20}$. Ele não tem escapatória. Quer escrever, mas o que sua escrita deseja é exatamente o lugar em que a linguagem
16. BLANCHOT, Maurice. O espaço literário, 2011, p. 47.

17. Idem. O livro por vir, 2005, p. 9.

18. Ibidem, p. 11.

19. BARTHES, Roland. "A morte do autor", 2004, p. 61.

20. BLANCHOT, Maurice. O espaço literário, 2011, p. 48. 
21. HOMERO. Odisséia, 2004, p. 215 .

22. BLANCHOT, Maurice.

O espaço literário, 2011, p. 29.

23. Idem. O livro por vir, 2005 , p. 75 . cessa de ser um poder, em que todas as experiências precisam ser negadas para que, de algum modo, possam se afirmar.

Evocar o encontro com as sereias não é tarefa simples. Talvez por isso Blanchot o considere como a repetiçáo do feito do grego: há sempre o risco da perda. Escrever torna-se a possibilidade de não escrever, pois o que se quer nomear é o inominável. Fonte de todo canto, o lugar de coro das sereias precisa ser negado se quiser ser cantado. Assim, para que Homero diga: "traz para cá teu navio, que possas o canto escutar-nos" ${ }^{21}$, faz-se preciso que o verdadeiro canto, aquele que leva os marinheiros à perdição, cesse. De outra maneira náo se poderia concretizar a narrativa. Ela nasce do paradoxal jogo entre a essência da literatura e a própria literatura; uma é a negação da outra. Foi esse o grande golpe que as sereias desferiram contra Ulisses. Tendo ouvido o canto e sobrevivido, ele deseja reproduzi-lo e, mais que isso, dominá-lo, arrastá-lo às regióes de sua força e moldá-lo para que se eternize em sua boca e memória. Mas - e nisso consiste a astúcia das sereias - o canto é o lugar em que fala o silêncio. Sua voz não pode ser reproduzida pela fala humana, pois se opóe a todas as palavras, é interminável e incessante, não fala. Ulisses não pode reproduzi-lo. Ao evocá-lo, ele o distancia, cobre sua natureza essencial com uma capa ilusória de linguagem, converte-se inevitavelmente em Homero, aquele que conta, mas que não viu nem ouviu o canto das sereias.

[...] aquele que escreve é igualmente aquele que "ouviu" o interminável e o incessante, que o ouviu como fala, ingressou no seu entendimento, manteve-se na sua exigência, perdeu-se nela e, entretanto, por tê-la sustentado corretamente, fê-la cessar, tornou-a compreensível nessa intermitência, proferiu-a relacionando-a firmemente com esse limite, dominou-a ao medi-la. ${ }^{22}$

Homero e Ulisses, para que ocorra a narrativa, devem ser, portanto, a mesma pessoa. Enquanto se depara com o ponto central e astutamente dá meia volta, o escritor é Ulisses, é aquele que "ouviu" o interminável e não se entregou a ele. Houvesse feito, haveria conquistado a essência da literatura, que é silêncio e nada, mas teria perdido a coisa cuja essência conquistara. Desse modo, não escreveria, pois não sobreviveria à atração fatal que o levaria às profundezas. Seria um escritor de quem se poderia, contraditoriamente, ainda que com toda lógica, dizer: "Nunca escreveu nada", exatamente o que escreveu Blanchot a respeito de Joseph Joubert.

Tendo percebido a existência do ponto secreto, fonte e origem de toda literatura, Joubert dedicou seus esforços a alcançá-lo. Nesse movimento, sacrificou todas as suas pretensóes literárias. "Tudo indica que, até os quarenta anos, ele se sente pronto para produzir belos escritos, como tantos outros" ${ }^{23}$, a partir, po- 
rém, do momento em que se póe a escrever e faz da literatura uma questão, seus objetivos se modificam. Preferindo o centro à esfera, ele abandona todas as ambiçóes e, como os marinheiros encantados, atira-se ao lugar preferido, onde nada se pode dizer. Seu afundamento nesse espaço é tal que ele chega a afirmar: "Não tenho mais superfície", sobre o que Blanchot comenta:

"Não tenho mais superfície." O que, para um homem que deseja escrever, que sobretudo só pode escrever como arte, pelo contato com as imagens e pelo espaço onde elas se póem em contato, é uma afirmação penosa. Como falar a partir somente da profundeza, nesse estado de afundamento em que tudo é árduo, áspero, irregular? Coisa interior, coisa afundada. ${ }^{24}$

Mais que fazer livros, Joubert quis se tornar mestre do ponto extremo que, uma vez encontrado, dispensa toda escrita. Lugar árduo, áspero e irregular, o ambiente no qual se move é a vazia região-mãe da música a qual Blanchot nos diz que é estéril e completamente privada de música. Lugar das potências ancestrais, em que domina a solidão essencial, esse é o espaço da imobilidade, não se liga às circunstâncias reais nem se preocupa em se fazer entender. Joubert sabe que, nesse espaço, entendimento e razão são insuficientes, ele sabe que ali não convém dizer coisa alguma, verdadeira ou falsa, pois que a "coisa interior" na qual está afundado é exterior a toda verdade e razão. Ele reconhece que esse lugar sem superfície é o domínio puro da arte, a essência primeira, através da qual ela vem a ser.

Alojado na profundidade, Joubert se interessa mais pela arte que pela obra, sabe que uma é a negação da outra e que, para que a segunda fale, é preciso fazer calar a primeira. Ele está, contudo, enfeitiçado pela voz das sereias, ouvindo a fala errante, incessante e interminável e esperando, quem sabe, o seu termo, para colocar-se no trabalho de escrever. Mas a voz não cessa nem termina, e seu livro é apenas silêncio e nada, onde reina o infinito e o pleno. Cônscio de que sua escrita não deseja menos que o ilimitado, Joubert se furta a escrever, pois sabe que toda escrita é território do limite, uma trajetória em torno do ponto central. Desviando-se do pouco a pouco que as palavras são capazes de fornecer, ele quer dizer tudo ao mesmo tempo, de uma única vez, sem interrupção alguma. Joubert deseja escrever o infinito.

O que supóe tanto um pensamento completamente diverso daquele dos raciocinadores, que caminha de prova em prova, quanto uma linguagem totalmente distinta da do discurso (preocupaçóes essências do autor dos Carnês). O que supóe, mais profundamente, o encontro ou a criaçáo daquele espaço de vacância onde, nenhuma coisa particular vindo romper o infinito, tudo está como que presente na nulidade, lugar onde nada terá lugar senáo o lugar [... $]^{25}$
24. Ibidem, p. 72.

25. Ibidem, p. 86. 
26. Ibidem, p. 10.

27. Joubert, apud. BLANCHOT, Maurice. O livro por vir, 2005, p. 77.

28. BLANCHOT, Maurice. $O$ livro por vir, 2005, p. 89.
O infinito é o canto das sereias, é ele que o escritor deseja colocar em seu livro, o livro supremo que nunca será escrito, pois a fala das sereias é contínua, nunca se pode começá-la nem terminá-la. Daí que toda obra é incompleta, pois sempre um algo virá romper o infinito e pôr em limites o que não possui arestas. Blanchot chama a isso de livro e lamenta que o inaudível canto se torne "infelizmente um livro, nada mais do que um livro" ${ }^{26}$. Não obstante a impossibilidade, é sempre para esse centro de silêncio que se direciona o escritor, em seu frustrado trabalho, que nunca está completo, mesmo quando hipoteticamente terminado, como adverte o autor dos Carnês: "Acabar! Que palavra! Náo acabamos quando paramos ou quando declaramos ter terminado" 27 .

Autor de não mais que fragmentos, reflexóes sobre o ato de escrever, dispostos no que hoje se conhece por Carnês, Joubert recusou-se a escrever o táo esperado livro acerca do qual seus amigos sempre questionavam. Ele fracassou, aparentemente. "Mas preferiu esse malogro ao compromisso do êxito"28. Diferente de Ulisses, seus feitos se engolfaram no profundo mar. Preferindo a origem a um canto limitado, Joubert é o marinheiro que se recusa a virar Homero e que se entrega por completo à solidão essencial da obra, que o priva do mundo, da glória e da luta diligente por seus livros.

Mas se é penosa a situação de Joubert, a do escritor que, como Ulisses, dá meia volta e se converte em Homero também não é fácil. Condenado a traduzir um idioma impraticável, ele se vê na soleira entre dois mundos, que o premem e exigem, cada um à sua maneira; e aos quais, sob nenhuma hipótese, ele pode recusar. Sendo aquele que entrou no entendimento da fala neutra, seu desafio agora é o de torná-la humana e dotada de forma. Nesse trabalho, um novo embate se descortina, o embate duro entre a voz das sereias e as cordas no mastro, em que cada um dos elementos, buscando absoluto domínio sobre o indivíduo quer, ao mesmo tempo, coexistir absolutamente com o outro, seu antípoda.

A esse trabalho homérico - em todos os sentidos - do escritor que se aproximou do centro, dedicaremos a próxima seção, buscando ver como, afinal, contribui o canto das sereias para a construção da literatura enquanto obra, não apenas enquanto essência.

\section{A arte de Homero}

A figura das cordas que seguram Ulisses e o impedem de empreender o salto definitivo em direção à obra e sua so- 
lidão essencial pode ser encarada como a condição sine qua non do escritor: um homem comum lutando contra forças abismais. Nessa luta, o homem sente o inevitável desejo de entregar-se e anular-se, desaparecer no vazio da obra. Mas as cordas o impedem, e elas são, como o canto que atrai, também uma fala. Sua fala, porém, não é a original, canto inaudível; é fala humana.

O homem fala. Falamos quando acordados e em sonho. Falamos continuamente. Falamos mesmo quando não deixamos soar uma palavra. Falamos quando ouvimos e lemos. [...] Falamos porque falar nos é natural. Falar não provém de uma vontade especial. Costuma-se dizer que por natureza o homem possui linguagem. Guarda-se a concepção de que, à diferença da planta e do animal, o homem é o ser vivo dotado de linguagem. ${ }^{29}$

Essa fala naturalmente humana se configura pelo som e presença, opondo-se àquela primeira, marcada por silêncio e ausência. Essa fala com que somos naturalmente dotados possui caráter pragmático e serve para que os homens comuniquem sensaçóes e pensamentos. Para Heidegger, de acordo com o que lemos, é exatamente esse falar que diferencia o homem das demais formas de vida. Ele é o modo como nos organizamos e nos classificamos, é nossa via de acesso ao mundo, sem a qual estaríamos completamente à mercê daquela voz ancestral, que desclassifica e tira de tudo sua identidade, é o modo como nos opomos a ela e à mudez encantatória.

Sendo portador dessa voz, Ulisses não quis despojar-se dela. Antevendo a glória que lhe adviria por haver enfrentado as perigosas sereias e sobrevivido, sua preferência foi a do seu canto, canto humano por meio do qual a Odisseia se fez. Também canto limitado, como já vimos. O modo de seu cantar, contudo, não é simplório. Sua ligação com o ponto central — ligação de negação, mas ainda assim uma ligação - lhe confere o signo da complexidade.

Arrastado de volta pela força das cordas, ou seja, de sua fala humana, Ulisses vê-se condenado a falar (mesmo seu silêncio seria uma fala, de acordo com Heidegger, mas não é o silêncio que ele escolhe). Condenado a falar, é à narrativa, não ao romance, que ele recorre. $\mathrm{O}$ ato de sua escrita não é o inofensivo translado de uma realidade dada para uma realidade escrita, é o ato doloroso da construção de uma escrita difícil, pois, lembremo-nos, ele trará de volta seu encontro com as sereias. Desse modo, mesmo valendo-se de uma fala humana, o agora escritor precisará moldá-la ao propósito de seu trabalho. E para tal, a fala comum torna-se inútil e faz-se necessária a utilização de uma outra linguagem.

Essa linguagem precisa apresentar-se como linguagem dentro do processo de escrita se quiser ser a presença do evento entre
29. HEIDEGGER, Martin.

"A linguagem", 2008, p. 7. 
30. BLANCHOT, Maurice.

O espaço literário, 2011, p. 33.

31. Idem. "A literatura e o direito à morte", 1997, p. 313.
Ulisses e as sereias. É por isso que uma linguagem comum não basta, pois, no seu exercício, "a linguagem cala-se como linguagem" 30 e deixa falar os seres, enquanto que no processo da narrativa blanchotiana o que precisa falar não são os seres, mas a própria linguagem, como diz Barthes no seu já citado "A morte do autor". Mas como calar os seres e deixar que a linguagem fale?

Para responder a essa questão, Blanchot estabelece distinçôes entre a fala comum e a fala do poeta. A primeira ele associa ao caráter representativo da linguagem, em que cada palavra tem o seu correspondente exato no mundo. Isso leva a linguagem a calar-se enquanto tal, uma vez que ela se converte em mero instrumento de comunicaçáo e de relaçáo do homem com o mundo e com os objetos. Nesse processo, enquanto anulaçáo de si mesma, ela permite que os seres falem e que, a partir dela, tornem presentes as coisas e as transmitam a outros. Ela desaparece para que o mundo surja. Essa desaparição, contudo, é ilusória, como Blanchot nos mostra:

A linguagem corrente chama um gato de gato, como se o
gato vivo e seu nome fossem idênticos, como se o fato de
nomear não consistisse em reter dele somente a ausência, o
que ele não é. Todavia, a linguagem corrente tem momen-
taneamente razáo nisto: a palavra, se exclui a existência do
que designa, remete-se ainda a ela pela inexistência que se
tornou a essência dessa coisa. Nomear o gato é, se o quiser-
mos, fazer dele um não-gato, um gato que cessou de existir,
de ser o gato vivo, mas náo por isso fazer dele um cáo, nem
mesmo um não-cáo. Essa é a primeira diferença entre lin-
guagem comum e linguagem literária. A primeira admite
que a não-existência do gato, uma vez passada para a pala-
vra, leva a que o próprio gato ressuscite plena e certamente
como sua idéia (seu ser) e como seu sentido: a palavra lhe
restitui, no plano de ser (da idéia), toda a certeza que ele
tinha no plano da existência. ${ }^{31}$

Tal como ocorre à linguagem literária, a fala comum também é marcada pela ausência. Para que algo seja nomeado, é preciso que esse algo se faça ausente e se torne presente táo somente na palavra, que é sua negação. É, portanto, por meio da negação que a fala comum afirma, pois, embora negação, ela só se concretiza a partir da existência do que nega. A discrepância, contudo, não é fatal e parece passar despercebida. A ausência que é a linguagem se torna presença sem grandes obstáculos, graças ao pragmatismo do qual está impregnada. Constrói-se, assim, um ambiente estável, sobre o qual é possível assentar bases seguras para a comunicação entre os homens e para a classificação e compreensão do mundo. A certeza dada às palavras torna-se desse modo mais sólida que a certeza do que existe, uma vez que os conceitos se firmam e as coisas não. 
Apesar do paradoxo, temos, nesse caso, uma linguagem tranquila e coberta de razão. $\mathrm{O}$ mesmo, porém, não podemos dizer da linguagem literária. Sendo uma fala humana, como a fala corrente, dela se diferencia em um aspecto. Diferente da fala comum, que encontra sua força motriz no mundo, a fala literária encontrará seu motor fora de qualquer esfera humana. Seu ponto de partida e de chegada é aquele lugar essencial representado pelo canto das sereias, lugar inalcançável, onde impera um silêncio absoluto. Assim, mesmo pertencendo aos domínios do homem, essa fala escapa a sua autoridade, não sendo uma fala comum e sossegada, como a que acabamos de ver. Dela, Blanchot diz: "A linguagem literária é feita de inquietude, é feita também de contradições" 32 . O paradoxo sobre o qual se assenta toda linguagem humana e que passa por inexistente na fala comum, é, no campo literário, condição a que não se pode ignorar. Enquanto o gato, ao ser nomeado, ganha solidez no dizer ordinário, no campo de ação do escritor, ele se esvanece, desaparece e se distancia, não deixando qualquer rastro atrás de si. Blanchot pergunta: "o que significará então tornar ausente 'um fato da natureza', apreendê-lo por essa ausência, 'transpô-lo em seu quase desaparecimento vibratório?"”, ao que ele próprio responde: "Significa essencialmente falar" ${ }^{33}$.

É essa a função da linguagem literária: fazer as coisas desaparecerem. Como a linguagem comum, para que ela comece, é preciso que o mundo se cale e se torne ausente, é preciso, como diz Blanchot, que a vida "tenha feito a experiência do seu nada, que ela tenha 'tremido nas profundezas e tudo que nela era fixo e estável tenha vacilado"'34. Isto quer dizer que toda linguagem se assenta sobre o vazio. Esse vazio é fundamental na distinção das linguagens, pois é através da relação que elas estabelecem com ele que se discernem entre literária e comum. Esta última dá ao vazio a aparência de presença e com isso consegue criar sentidos fixos para as coisas, mesmo quando elas são instáveis. Nisso difere daquela, marcada principalmente por se interessar pela ausência. Mais que a fala cotidiana, ela cumpre bem sua designação de tornar ausente um fato da natureza e apreendê-lo por sua ausência, pois ela náo ignora que, no processo de dizer, o que se torna ideia não é a coisa existente, mas sua não existência. Essa linguagem "observa que a palavra gato não é apenas a não-existência do gato, mas a não-existência que se tornou palavra" ${ }^{35}$. Consciente dessa metamorfose, a fala da literatura se torna inquieta, pois não se contenta com a limitada transposição do irreal para a realidade reduzida da palavra. Ambiciosa, quer apreender o vazio em sua completude. Para isso, deixa o mundo e suas certezas e parte em busca daquele nada que tấo tacanhamente nomeou. Nesse processo, afrouxa os laços dos sentidos e faz das palavras realidades cambiantes, cujos significados não são fixos nem dados previamente. Ela aproxima a palavra da "li-
32. Ibidem, p. 313.

33. Idem. O espaço literário, 2011, p. 32.

34. Idem. "A literatura e o direito à morte", 1997, p. 312.

35. Ibidem, p. 313. 
36. Ibidem, p. 314.

37. Ibidem, p. 314.

38. Ibidem, p. 315. berdade selvagem da essência negativa”, ou, em outras palavras, do centro do canto mítico das sereias, em que tudo se cala, pois significado algum resiste naquele ambiente de vazio e nada.

Assim começa essa perseguição pela qual toda linguagem, em movimento, é chamada para responder à exigência inquieta de uma única coisa privada de ser, a qual, após ter oscilado entre cada palavra, procura retomá-las todas, para negá-las todas ao mesmo tempo, a fim de que designem, nele submergindo, esse vazio que elas não podem preencher nem representar. ${ }^{36}$

Ao contrário da linguagem cotidiana, esta possui designativos ligados ao movimento, como vemos na citação transposta. Sua busca pela impossibilidade a investe do signo do desassossego. Na tentativa de responder à exigência inquieta da obra, a fala nunca encontra repouso, pois o que quer designar sempre lhe escapa e ela é, a cada vez, renegada pela substância negativa de que tenta se apropriar, não sendo jamais o contato direto com o objetivo, mas uma realidade apartada e completamente diversa. Essa rejeição por parte do nada a que se quer chegar se dá porque, sendo uma fala humana, a linguagem, mesmo a literária, é a oposiçáo da fala errante. Ela quer achegar-se a esse nada, mas ele lhe é anterior, é uma fala ancestral, alheia a toda razão e objetividade. "A linguagem sabe que seu reino é o dia, e não a intimidade do não-revelado" ${ }^{37}$. É por isso que, à semelhança das cordas que amarravam Ulisses, a linguagem é um recuo ante a solidão essencial, pois, no ambiente absoluto, nenhum sentido está amarrado e fixado. Ali, todas as coisas, livres da fala humana, encontram aquela liberdade selvagem que citamos há pouco.

Mas a linguagem literária é exatamente o movimento para esse espaço do qual ela é a negação. Para que exista é preciso que não apenas o mundo seja renegado, mas que também a fala errante da qual o poeta ouviu o murmúrio se cale. Como Homero em seu ofício, a linguagem deseja o canto das sereias. Mas a existência de Homero se deve ao fato de que Ulisses renegou a música sobrenatural. Para que Homero, bem como a linguagem, exista é preciso excluir algo, esse algo é o vazio e o nada, o cerne da voz das sereias, que eles têm como objetivo. Esse é, pois, o tormento da língua: sempre lhe falta algo exatamente pela necessidade que ela tem de ser esse algo que falta. Nesse impasse, Blanchot vê uma saída, não muito esperançosa. Diz ele: "Onde reside entáo minha esperança de alcançar o que rejeito? $\mathrm{Na}$ materialidade da linguagem, no fato de que as palavras também são coisas" 38 .

Blanchot reconhece que todo o esforço da linguagem de alcançar a essência, ou existência, das coisas resulta na obtenção de uma única existência: a da própria linguagem. Sendo, 
pois, uma realidade dada, uma coisa, as palavras não podem representar outras coisas. Sendo um "maciço de existência", elas não podem deixar que nada fale por seu intermédio, senão elas próprias. Diferente da língua do dia a dia, que desaparece em si mesma, levada pelo uso e pela utilidade, a fala literária, incapaz de comunicar, dada sua mobilidade de sentidos, se instaura enquanto linguagem. Movendo-se em direção à fala errante, toma de empréstimo dessa o isolamento do indivíduo que a produz, não se submetendo à sua intenção de representação de mundo, seres, opiniōes ou sensaçóes. É desse modo que ela se deixa falar e faz calar os seres.

Nessa fala, já não somos devolvidos ao mundo, nem ao mundo como abrigo, nem ao mundo como metas. Nela, o mundo recua e as metas cessaram; nela, o mundo cala-se; os seres em suas preocupaçôes, seus desígnios, suas atividades, não são, finalmente, quem fala. $\mathrm{Na}$ fala poética exprime-se esse fato de que os seres se calam. ${ }^{39}$

Os seres se calam e só a linguagem fala, não sendo apenas ausência do que se quer, mas a presença dessa ausência. Assim, escondidas no seio do canto humano, as sereias obrigam esse canto a lhes fazer menção, elas o fazem ceder à sua exigência, fazendo dele a afirmação de um espaço vazio. Falando sozinha, tendo em si própria seu fim, de que fala, então, essa linguagem poética? De nada. Ou melhor, é o nada que fala nela, como explica Blanchot: "é um nada que pede para falar, nada fala, nada encontra seu ser na palavra, e o ser da palavra não é nada. Essa fórmula explica por que o ideal da literatura pôde ser este: nada dizer, falar para nada dizer" ${ }^{\prime 4}$.

Nesse complexo processo de construção da linguagem, o escritor empreende o movimento dos opostos. Seu ato é a re-encenaçáo do duelo entre Ulisses e as sereias. Agora, contudo, o combate não se dá no mar, mas na mesa do escritor. Querendo atender à exigência da obra, ele busca aproximar-se do nada de onde ela promana, ao mesmo tempo em que se afasta dele, interpondo entre ambos a realidade concreta e ilusória da linguagem literária. Sobre esse duelo, mais caseiro embora não menos árduo, de construção dessa linguagem ímpar, Blanchot também se deteve, dando atenção ao modo como as forças até aqui descritas atuam na elaboração do feito artístico. Vejamos:

Acontece que um homem que segura um lápis, mesmo que queira fortemente soltá-lo, sua mão, entretanto, não o solta, ela fecha-se mais, longe de se abrir. A outra mão intervém com mais êxito, mas vê-se então a mão a que se pode chamar doente esboçar um leve movimento e tentar retomar o objeto que se distancia. ${ }^{41}$
39. Idem. O espaço literário, 2011, p. 35.

40. Idem. "A literatura e o direito à morte", 1997, p. 312.

41. Idem. O espaço literário, 2011, p. 15. 
42. Ibidem, p. 15.

43. Ibidem, p. 21.

44. Ibidem, p. 16.
Essa é a imagem de que se vale nosso teórico para ilustrar o que ele chama de preensão persecutória. Detentora do lápis, a mão do escritor deseja mantê-lo ativo, agindo mesmo contra as intençôes de seu possuidor. Sua ação só é estagnada quando a outra mão intervém e lhe arranca o instrumento, colocando-o em inação. Possuidora de um desejo incontido de escrever, contudo, a primeira mão, não cedendo ao esforço da outra, persegue-a na tentativa de recuperar o objeto perdido. É esse o movimento que recebe a designação apresentada e é para ele que atenta Blanchot, para a estranheza de sua realização: "O que é estranho é a lentidão desse movimento. A mão move-se num tempo pouco humano, que não é o da ação viável, nem o da esperança, mas, antes, a sombra do tempo" ${ }^{\text {‘2 }}$. Tempo pouco viável o dessa mão doente, ele é o mesmo que o autor associa com a narrativa: tempo não humano, tempo inexistente, em que tudo se encontra presente, agora mesmo e já. Não obstante a perseguição e o desejo de retomar o lápis, essa mão não se importa em dar fim ao trabalho. Ela parece querê-lo sempre presente, sempre em trânsito, ela se recusa a dar-lhe um fim e entregá-lo ao passado. Atendendo ao apelo que lhe faz a fala errante, essa mão faz do escrever um "entregar-se ao fascínio da ausência de tempo" 43 . Desse modo, seu trabalho se torna impossível, pois, ainda que seja aquele que ouviu a linguagem sem entendimento, o escritor é, tal como o Orfeu blanchotiano, culpado de impaciência. Pouco afeiçoado à amplidáo do espaço da obra, ele interfere na sua composição enviando a outra mão, único elemento desse jogo que está sob seu comando, e ordenando-lhe que interrompa a escrita. É este seu único poder, e o seu erro: querer pôr um fim ao interminável.

O domínio do escritor não está na mão que escreve, essa mão "doente" que nunca solta o lápis, que não pode soltá-lo, pois o que segura, não o segura realmente, o que segura pertence à sombra e ela própria é uma sombra. O domínio é sempre obra da outra mão, daquela que não escreve, capaz de intervir no momento adequado, de apoderar-se do lápis e de o afastar. Portanto, o domínio consiste no poder de parar de escrever, de interromper o que se escreve, exprimindo os seus direitos e sua acuidade decisiva no instante. ${ }^{44}$

Mais uma vez indo de encontro ao senso comum, Blanchot associa ao escritor a possibilidade única de parar de escrever, aparentemente contrariando seus argumentos de que a escrita é uma ação do campo humano e, portanto, uma negação da fala errante. A contradição, de fato, existe, mas se justifica. Devemos lembrar que o processo de escrever, não obstante ser uma ação humana, é uma resposta à exigência da obra, que é isso que ela pede daquele que ouviu a linguagem impraticável. Desse modo, conquanto seja a negação do que a motiva, a escrita é o meio 
único de aproximaçáo desse ponto neutro, e só o é porque ele exige dessa maneira. Assim, embora seja o agente da escrita, o escritor não tem sob seu domínio a mão trabalhadora. Ela não age sob sua tutela; move-se como que sozinha, atendendo unicamente ao apelo da "doença" que a acomete, que é a afirmação da solidão. Enquanto indivíduo ao nível do mundo, só cabe a ele, escritor, cercear o poder que a obra exerce sobre si e sua máo. Só cabe a ele a decisão de enviar a outra mão para duelar com a primeira e subtrair-lhe o lápis. Sua única capacidade é essa, porque "escrever nunca é um poder de que se disponha" ${ }^{45}$.

Isso, contudo, náo the confere sossego. Ao interromper o caminho traçado pela obra, o escritor vê-se obrigado a tornar em paciência sua impaciência, pois o resultado de sua intervenção nunca é o produto final de um processo; é antes um fragmento, um exercício apenas. Ao privar a mão doente da posse do lápis, ele vê que não atingiu o que buscava, que seus planos não se concretizaram.

$\mathrm{O}$ escritor que sente esse vazio acredita apenas que a obra está inacabada, e crê que um pouco mais de trabalho, a chance de alguns instantes favoráveis permitir-lhe-ão, somente a ele, concluí-la. Portanto, volta a pôr máos à obra. Mas o que quer terminar continua sendo o interminável, associa-o a um trabalho ilusório. ${ }^{46}$

Assim, ele volta mais uma vez à busca da origem e entra mais uma vez na ausência de tempo. Ele se vê obrigado a conceder à máo, que por um instante fora privada de seu movimento, o poder de voltar a executá-lo, sem pressa, até ser novamente interrompida pela outra mão, símbolo da impaciência do escritor e de sua ligaçáo com o mundo, que o faz crer que uns instantes a mais poderão levá-lo a concluir o que começou. Mas no seu trabalho sem fim, a mão doente sabe que isso é impossível, ela sabe que o ponto central é inacessível e que, por isso, deve trabalhar para sempre, a fim de aproximar-se - não mais que isso — dele. É essa a imagem de Ulisses se debatendo amarrado ao mastro de seu navio. O desejo incontido de entregar-se ao infinito é tolhido pela força das cordas, que o prendem ao mundo e exigem que retorne.

Rimbaud é um exemplo claro desse incessante duelo causado pela preensão persecutória. Enquanto trata do tema, em um de seus ensaios, Blanchot lança a seguinte questão: "Por que é que, se ele [o escritor] rompe com a obra, como Rimbaud, esse rompimento nos impressiona como uma impossibilidade misteriosa?" ${ }^{47}$. A resposta reside, sem dúvida, na mão doente e no seu trabalho sem fim. Como, no caso de Rimbaud, teria essa mão e a doença que a acomete, finalmente, encontrado descanso? Em $A$ conversa infinita, o teórico nos esclarece. Mostra que a
45. Ibidem, p. 64.

46. Ibidem, p. 13.

47. Ibidem, p. 16. 
48. Idem. A conversa infinita, 2010, p.10. Grifo nosso.

49. Idem. "O sono de Rimbaud”, 1997, p. 153. sucumbência da preensão, no caso de que tratamos, não se deu de modo fácil e rápido - se é que se deu - como a História literária faz parecer ter acontecido. Após o "Adeus", que encerra Uma estadia no inferno, considerada como a obra final do jovem, na qual rompe com a literatura, ou toma a decisão do rompimento, Blanchot nos mostra que o poeta esteve envolvido com questôes de poesia. Ele explica:

Náo temos prova decisiva de que em Londres, um ano após a ruptura ou mais tarde, Rimbaud ainda evidenciasse ser poeta. Por outro lado, e em duas ocasióes, ele evidenciou ser literato: uma primeira vez ao copiar — passando a limpo - seus poemas em companhia de Germain Nouveau [...]; em seguida, em 1975 [sic], em Stuttgart, ao remeter a Nouveau, por intermédio de Verlaine, "poemas em prosa" "para serem impressos". Sabemos portanto que até 1875 ele conserva uma certa preocupação literária. Mesmo que não escreva, ainda se interessa pelo que escreveu, repisa os caminhos que traçou; mantém-nos abertos como uma possibilidade de comunicação com seus amigos. ${ }^{48}$

Dois anos após sua obra final, ainda vemos o jovem Arthur Rimbaud envolto com seus poemas, passando-os a limpo, preparando-os para a impressão. Blanchot diz que, embora não evidenciasse ser poeta, o autor de $A$ carta do vidente ainda mantinha tais escritos abertos como possibilidade de comunicação, como que admitindo que a intervenção da outra mão viera cedo demais e que talvez fosse preciso chamar a máo doente de volta ao trabalho. É nisso que acredita Blanchot. Para ele, a preensão persecutória nunca cessou de atormentar o poeta francês. Mesmo na sua recusa de ser poeta, a voz inaudível parecia exigir-lhe algo.

Dizer que a experiência de Rimbaud na época das Iluminaçôes e de Uma estação no inferno levou-o ao silêncio de Chipre, ao tráfico do Harar, às comunicaçóes com a Sociedade de Geografia, quer dizer que, de sua decisão de romper com a poesia, reconhecemos apenas uma sinceridade de fachada, já que, aventureiro, traficante de armas e explorador novato, ele teria continuado, sob outra forma e de maneira mais profunda, os mesmos objetivos, os mesmos desregramentos, a mesma busca do desconhecido do tempo dos esplendores poéticos. ${ }^{49}$

Ao dizer que de sua decisão de abandonar a poesia podemos reconhecer uma sinceridade apenas de fachada, Blanchot expóe sua crença de que Rimbaud jamais tenha abandonado, de fato, o mundo poético, como prova o fato de se ocupar ainda de seus escritos dois anos depois do declarado fim. Levanta também a hipótese de que o poeta tenha atendido à exigência através de seu modo aventureiro de viver, que, possivelmente, através dele, tenha atingido o objetivo de sua poesia: "ver mais do que pode 
ver, conhecer mais do que pode conhecer" ${ }^{\prime 50}$, ou, em outras palavras, o ponto central. Essa segunda parte, porém, nos parece bem mais hipotética do que realmente aceita por Blanchot. Para ele, Rimbaud atendeu à exigência da obra através da escrita. É certo que ele reconhece a má qualidade das cartas pós-Chipre. Diz que, aos amantes da literatura, elas se afiguram como mal escritas, decepcionantes e indignas de tão grande escritor. Mas afirma:

Por isso, o que nos espanta não é a má qualidade das suas cartas, mas, pelo contrário, o tom eternamente teimoso, furioso e sem ida nem volta que, através das fadigas, do trabalho e das renúncias de todas as espécies, até no leito de morte continua nele a perpetuar Rimbaud. ${ }^{51}$

Mesmo nos escritos considerados mais pobres atribuídos ao poeta, Blanchot reconhece o mesmo tom dos poemas e da grande fase, embotado, é claro, pelas fadigas do trabalho e pelas renúncias, mais ainda vivo e operante, acompanhando o poeta até o leito da morte.

Há ainda a questão das Iluminaçôes, das quais fala Blanchot, escritas depois do "Adeus" e que mostram a recusa do poeta diante da própria recusa. Embora escrita depois, essa obra não é tida por nosso autor como a última escrita por Rimbaud. Essa posição, vimos, é atribuída ao "Adeus". Para Blanchot, Iluminaçôes pertence a um tempo recusado e se configura como um excedente. Ele a vê como um livro escrito nos "interstícios dos dias [...] para que pudesse tomar lugar numa vida a partir de então - a não ser por 'fraqueza' - sem literatura" ${ }^{52}$. Parece um livro salvador, escrito para que o poeta pudesse suportar sua vida sem literatura. E se apresenta como prova da constância daquela mão portadora do lápis, não obstante ser, como diz Blanchot, preciosista, sinal, sem dúvida, da interferência daquela outra mão, serva das circunstâncias cotidianas, que intervinha no processo da escritura.

Até aqui vimos o caráter profundamente ambíguo que permeia a poética blanchotiana, representado pela figura de Ulisses, que enfrenta as sereias e depois se converte em Homero na tentativa de reproduzir o extraordinário fato. Entendemos como o canto ouvido pelo herói grego tem ligação com a solidão essencial da obra, fonte de todo exercício artístico e origem da natureza paradoxal e inquieta da literatura. $\mathrm{O}$ modo como essas forças antípodas - Ulisses e sua astúcia, as sereias e seu encanto — duelam na formação da linguagem literária vimos sob a imagem das mãos que disputam a posse do instrumento, querendo uma ceder ao fascínio da exigência da obra, e querendo a outra ceder às pressôes do mundo exterior, "ou seja, a história, a figura do editor, das experiências financeiras, das tarefas sociais, [que] pronunciam esse fim que falta" ${ }^{53}$.
50. Ibidem, p. 152.

51. Ibidem, p. 158.

52. Idem. A conversa infinita, 2010, p. 14.

53. Idem. O espaço literário, 2011, p. 12. 
Renegando a tradição mimética, Blanchot situa a origem da literatura fora do mundo, numa instância ancestral e absoluta, à qual o homem tenta achegar-se, mas que permanece interdita por natureza. Nessa interdição, nesse espaço fronteiriço, sua força de homem tenta captar o murmúrio inefável da fala errante, mas o que pode é apenas parcial, o que torna a literatura sempre um devir, sempre uma fala estrangeira dentro do idioma pátrio. A força das sereias contra a astúcia de Ulisses: uma luta desigual. 


\section{Referências}

BARTHES, Roland. "A morte do autor". In: O rumor

da língua. Tradução de Mário Laranjeira. São Paulo: Martins Fontes, 2004. p. 57-64.

. Aula. Tradução de Leyla Perrone-Moisés. São Paulo: Cultrix, 2007.

BLANCHOT, Maurice. A conversa infinita 3: a ausência de livro, o neutro, o fragmentário. Tradução de João Moura Jr. São Paulo: Escuta, 2010.

"A literatura e o direito à morte". In: A parte

do fogo. Tradução de Ana Maria Scherer. Rio de Janeiro: Rocco, 1997. p. 291-330.

O espaço literário. Tradução de Álvaro Cabral. Rio de Janeiro: Rocco, 2011.

. O livro por vir. Tradução de Leyla Perrone-Moisés. São Paulo: Martins Fontes, 2005.

. "O sono de Rimbaud". In: A parte do fogo.

Tradução de Ana Maria Scherer. Rio de Janeiro: Rocco, 1997, p. 151-158.

HEIDEGGER, Martin. "A linguagem” In: . A caminho da linguagem. Tradução de Márcia Sá Cavalcante Schuback. Petrópolis: Vozes/ Bragança Paulista: Ed. Universitária São Francisco, 2008. p. 7-26. . A origem da obra de arte. Tradução de Maria da Conceição Costa. Lisboa: Ediçôes 70, s.d.

HOMERO. Odisséia. Tradução de Carlos Alberto Nunes. Rio de Janeiro: Ediouro, 2004. 
